\title{
What do Indonesian Novelists Think About?
}

\author{
M Sudaryanto ${ }^{1}$, M Rohmadi $^{2}, \mathrm{C} \mathrm{Ulya}^{3}$ \\ $\left\{{ }^{1}\right.$ memetsudaryanto@staff.uns.ac.id, ${ }^{2}$ mamad_r76@staff.uns.ac.id, ${ }^{3}$ chafit@staff.uns.ac.id $\}$ \\ ${ }^{1,2,3}$ Universitas Sebelas Maret, Indonesia
}

\begin{abstract}
Literary work is defined as a representation of human life that is processed through the imaginative path of a writer. Novels as literary works that have a high level of complexity have the potential to have conflict complexity that is displayed implicitly or explicitly. This study aimed to identify the author's style of showing conflict in his/her novel. In addition, the conflicts that arise in the novel were compared to show the interest used to lead readers' opinions. The results showed that psychologically, most writers using the ego approach worked using a secondary process. The ego shown in the novels is dominated by the ideal ego which shows that personality of superego in the context of human behavior becomes a system that forms moral and ethical values used to shape the perfect human personality. Superego tends to oppose both id and most novelists in Indonesia describe the differences of the main figure and the gradual supporting figure. The degree of superiority of the figures is stratified.
\end{abstract}

Keywords: Novelist, Id, Ego, Superego

\section{INTRODUCTION}

Literary works are s a form of expression of ideas to be conveyed and felt by the author about everything around him/her. Literary works are manifested from the ideas to be conveyed by a writer using the arts of language in such a way. Implicitly, they contain elements of meaning and moral messages. The moral message includes educational values that can be used as an experience for the reader. Literary works are also created to be enjoyed, understood, and used by the society. In literary works, there are forms of expressions of thoughts, attitudes, feelings, responses of the author about the life experienced and faced. Most of the author's personal experience documenting tools are novels [1].

The novel reveals deep aspects of humanity and are presented in different styles because the events in the novel are created from a conflict or dispute that exists in both human real and imaginative lives. Conflict or figure disputes in the novel are supported by the author's style of telling the problems experienced by the main figure. The main figure becomes the center of attention when reading a novel. The conflict experienced by the main figure will make the story in the novel more alive [2]. Conflicts can occur between one figure and another and with the figure him/herself. A figure's conflict with oneself is known as an inner conflict.

As a work of imagination, the novel has a different scope, in which there are various kinds of figures to whom the author has given different characters. The author will display the character through a problem or conflict in the story. Psychology as one branch of science has a theory to study the figure's character in literary works, in conjunction with psychology literature that has a special room to observe the behavior of the figures in the story. From the opinion above, it can be concluded that literary works are the author's way of expressing the perspective 
of life in form of language in the story. Meanwhile, the literary psychology emphasizes the psychological aspects to understand the figure's personality and traits in the literary work [3].

The author usually describes the figure in terms of physical characterization while describing the figure's character with characterization. Personality includes the way the figure dresses and his/her daily appearance while characterization includes the traits and characters of each figure. Generally, readers of novels whose imagination has been led by a novel will create their own conflicts. This is due to psychiatric problems in literary works, especially the characterization that emphasizes the psychological aspects so that the reader can imagine the main figure as him/herself. In general, conflicts can be observed due to several characteristics, which occur in every person with different reactions to the same stimulus. This depends on personal factors [4]. Conflicts occur when motives have a balanced value or approximately the same, causing vacillation and tensions. Conflicts can last for a short time, maybe a few seconds, but can also last long, for days, months, even years. Then, it can be concluded that the conflict is an event which is motivated by something (hope, purpose, willingness) that conflicts with each other and causes uncomfortable feelings. Conflicts can be caused by several factors that can affect the main figure both physically and psychologically.

Based on the writing style of the novel used by the author, it shows that psychoanalyst is a school of thought assuming that humans are a form of collaboration between instincts and personality structure conflicts [5]. The contradictions within the personality structure are the result of the imbalance of the id, ego, and superego structures in humans. Behaviorism is a school of thought that considers humans to be the victim who is susceptible to environmental stimuli. Humanistic psychology shows human behavior from the different perspectives from psychoanalysis and behaviorism.[6]

Sigmund Freud's theory of literary psychology is also called the theory of psychoanalysis. Sigmund Freud's psychoanalytic theory says that human life is dominated by his/her unconscious nature [2]. Not long after that, Freud revised his opinion, especially about the consciousness and unconsciousness, and then introduced the theory of personality. He then divided the personality into three types, namely id, ego, and superego.

\section{RESEARCH METHOD}

This study used a qualitative approach with content analysis methods. The findings were compared to find similarities and differences in style revealing conflicts in the novel with a psychology of literature approach. The data in this study were documents, i.e. best-selling novels, including the novels by Tere Liye, Dee, Andrea Hirata, and Anwar Fuady. The data were then analyzed using Miles and Huberman's theory [7], namely interactive analysis techniques consisting of data collection, data reduction, data display, and conclusion drawing. The data in this study were the novel analysis results. The personality attached to the main figure, the inner conflict inherent in the figure, and the resolution of the conflict experienced by the figure were described by the researcher in words and sentences. The data were validated using the triangulation technique, namely the triangulation of theories, methods, and researchers.

\section{RESULT AND DISCUSSION}

Most of the portrayals of the figure's characters in fiction are depicted in three dimensions, namely the psychological dimension (psychiatric), physical dimension (jamaniah), and the sociological dimension (background, rank and position). Physical dimension is the physical 
state of the figure related to age, physical characteristics, illness, self-condition, and so on. The sociological dimension describes ethnicity, occupation, social class, wealth background, rank and position. Then, the psychological dimension is the most important main factor in describing the figure's character or temperament, whether he/she is kind, gentle, arrogant, evil, and so on [8].

Characterization is the way an author describes the characters and traits of each figure in a story . Physical dimension is the physical state of a figure related to age, physical characteristics, illness, self-condition, and so on. The physical dimension is related to the physical characteristics seen by the five senses, can be directly identified, and is the most visible in real terms. The sociological dimension describes ethnicity, occupation, social class, wealth background, rank and position. The sociological dimension is related to something that is abstract and relates to the relationships made by individuals to others. Then, the psychological dimension is the most important main factor in describing the figure's character or temperament, whether he/she is kind, gentle, arrogant, evil, and so on [9]. Psychological dimension is closely related to the traits and characters that distinguish one figure from another.

Personality and characterization are very closely related. Personality is the author's way of describing the figure clearly including physical appearance, dressing method, and habits. Characterization is the way an author describes the characters and traits of each figure in a story. Character refers to the character that exists in everyone who has traits, attitudes, interests, desires, the way of thinking and perspective of the figures. The behavior displayed in a story will give a certain impression to the reader as if they are drowned in the story. That behavior is positive, has a positive will, and is morally positive or even vice versa. The similarity of other studies is that this study has the same style as other authors do in describing the character.

Nyoman Kutha Ratna [10] explains that the personality theory, according to Sigmund Freud, is generally divided into three, namely: (a) Idea or Es, (b) Ego or Ich, and (3) Superego or Uber Ich. The literary psychology approach is used to study the inner conflicts of the main figures in a story. The study of intrinsic elements such as themes, figures or characterizations, plot, point of view, and background is not analyzed in more detail given that the focus of this study is using a literary psychological approach.

The inner conflict is viewed from the Personality Structure of Id System (Das Es). The id aspect is an aspect that is carried from birth, so it is called the original aspect. The id aspect works based on the subconscious principle and is controlled by human instincts and libido to be fulfilled immediately. Instincts that must be fulfilled can be biological or psychological aspects, such as eating and drinking, picnics, and so on. Id works based on the principle of pleasure and tension avoidance. Id is the only component of personality that is present from birth or the basic system of personality. The personality aspect is fully conscious and is included in instinctive and primitive behaviors. Some novelists use Id in the main figure to manage pleasures, namely the principles that generally prioritize comfort conditions and avoid conditions that tend to be dangerous or uncomfortable [11].

The analysis of the main figure's inner conflict in terms of his/her personality structure of the ego system (das ich). Ego is the part of the mind that represents the subconsciousness. Ego works using a secondary process, which is full of consideration, common sense, and strength to delay spontaneous responses to external stimuli or to instinctive urges from within. It serves to produce change that is quite useful in the external world for its own sake (through activities) [12]. In looking at internal activities, regarding ideas, ego does its task by controlling instinctive demands by deciding whether those demands are worthy of satisfaction, delaying satisfaction in accordance with the time and situation that allows for the external world, or suppressing the tension of feelings completely. 
Ego shown in the novels is dominated by the ideal ego which shows that the main figure's personality is of good value. He/she can recognize good or bad values (conscience) so that his/her personality acts in accordance with the morals of society. The similarity is that both study the ego of the main figure in depth.

Superego in the context of human behavior becomes a system that forms moral and ethical values used to shape the perfect human personality. Superego tends to oppose both id and ego and make the world in its own image. Superego actions lead to perfection rather than pleasure. Superego is the moral and ethical power of personality, which operates using the idealistic principle as opposed to the id satisfaction principle and the realistic ego principle. Superego is essentially an element that represents good and bad values so that humans understand based on their experience in life. Superego is a moral institution, the result of experience, tradition and culture. As a sociological aspect, it connects individuals with tradition and culture as a whole. Another superego that is seen from the main figure is a superego who opposes the ego.

Many novelists in Indonesia illustrate the difference between the main figure and the gradual supporting figure, the degree of superiority of the main figure, the primary main figure, the supporting main figure, the main supporting figure, the additional (winning) supporting figure. Thus, this method can be used as one simple analysis to determine which figures will survive to the end [13]. What people do in the form of actions and behaviors in many literary works is a way to show reactions, responses, traits, and attitudes that reflect the nature of their selfishness. The figure's behavior in novels that is easy to control situations is usually used as a means of influencing the reader. Some authors place circumstances that make the main figure must make hard decisions. The main figure can choose which to do first [14].

Conversations conducted by the figures are usually also intended to describe the characteristics of the figures concerned. A good conversation reflects the figure's selfishness. The discussion of verbal actions of the main figure's characteristics can also be extended to the way the author shows the main figure's nonverbal actions. Many events in the past of the main figure that shape his/her character of the present.

\section{CONCLUSIONS}

The novel reveals deep aspects of humanity and are presented in different styles because the events in the novel are created from a conflict or dispute that exists in both human real and imaginative lives. Some authors describe the figures from a physical point of view through characterizations mostly shown through the style of dress, way of speaking, and personal character. Meanwhile, the figure's characters are described by characterization. The characterization used in most novels is the trait and character of each figure. The inner conflict is viewed from the Personality Structure of Id System (Das Es). The id aspect is an aspect that is carried from birth, so it is called the original aspect. The id aspect works based on the subconscious principle and is controlled by human instincts and libido to be fulfilled immediately. Instincts that must be fulfilled can be biological or psychological aspects, such as eating and drinking, picnics, and so on. Id works based on the principle of pleasure and tension avoidance. Id is the only component of personality that is present from birth or the basic system of personality. The personality aspect is fully conscious and is included in instinctive and primitive behaviors. 


\section{REFERENCES}

[1] J. Tanenbaum, K. Tanenbaum, and R. Wakkary, "Design fictions," in Proceedings of the 6th International Conference on Tangible, Embedded and Embodied Interaction, TEI 2012, 2012.

2] M. Al Hafizh, F. Faruk, and J. Juliasih, "Identifikasi Ideologi dan Pola Relasinya dalam Novel--Novel Jacqueline Woodson,” ATAVISME, 2016.

[3] T. Suwondo, "Studi Ilmiah Sastra: Antara Realitas dan Harapan," Al-Qalam, 1999.

[4] R. J. Hobbs, E. Higgs, and J. A. Harris, "Novel ecosystems: implications for conservation and restoration," Trends Ecol. Evol., 2009.

[5] "TINDAK TUTUR DIREKTIF DALAM WACANA NOVEL TRILOGI KARYA AGUSTINUS WIBOWO,” Seloka J. Pendidik. Bhs. dan Sastra Indones., 2015.

[6] M. Hammersley, "Ethnography: problems and prospects," Ethnogr. Educ., 2006.

[7] M. B. Miles and M. A. Huberman, Analisis Data Kualitatif: Buku Sumber Tentang Metode-Metode Baru. 2012.

[8] K. A. Kusuma, H. J. Waluyo, and N. E. Wardani, "Pengakuan Calabai: Sebuah Analisis Intertekstual Novel Pasung Jiwa Karya Okky Madasari Dan Novel Calabai Karya Pepi Al-Bayqunie," J. KATA, 2018.

[9] L. Cahill and J. L. McGaugh, "A Novel Demonstration Of Enhanced Memory Associated With Emotional Arousal,” Conscious. Cogn., 1995.

[10] N. K. Ratna, "Antropologi Sastra: Penggunaan Teori dan Metode secara Eklektik dan Metodologi Campuran," PUSTAKA, 2012.

[11] L. Zhang, "Reading and Writing Connections," in The TESOL Encyclopedia of English Language Teaching, 2018.

[12] G. Bull and M. Anstey, "Using The Principles Of Multiliteracies To Inform Pedagogical Change," in Multiliteracies in Motion: Current Theory and Practice, 2009.

[13] J. R. Johnston, K. Breunig, C. Garrity, and A. Mitchell, Through the Eyes of Children : Healing stories about divorce. 1998.

[14] N. Erisha, "Implicature Found In The Slogans Of Life Insurance AdvertisementS," J. Lang. Lit. Vivid J. Lang. Lit., 2015. 